\title{
IV. On the agency of electricity in constituting the peculiar properties of bodies, and producing combustion
}

\section{Mr. John Webster}

To cite this article: Mr. John Webster (1814) IV. On the agency of electricity in constituting the peculiar properties of bodies, and producing combustion, Philosophical Magazine Series 1, 43:189, 17-20, DOI: $10.1080 / 14786441408637959$

To link to this article: http://dx.doi.org/10.1080/14786441408637959

电 Published online: 27 Jul 2009.

Submit your article to this journal $\pi$

Џll Article views: 2

Q View related articles $\sqsubset$ 
On the Agency of Litctricity in preducing Combistion. 17

direct and sulien, the mole above recommended should be pursued: if indireci, and in chmecuenee of iong exposure to the cause, as is orinarily the cese in the fiects produced by cola'; heat, as in this instance, shouid be chutiousty and gradially a plied, with friction, $8 \mathrm{ro}$.

P. S.- Dily experience wirants ne in asserting, that in all instances of bum and saldi, which athit of the total exclusion of the extemal air, as in the modis of inmersion and poulticing before mentioned, the best method is to omit entirely, furing that process, any dressing to the part, although the cutis be left denuded.

To this mode I attribuic the complete success in the last instance, in which case much of the culicle was entirely destroyed or detached by the fire; the sedative and asiringent qualities of the satumine preparation acting conjointly with the cold, in constringing and closing the critices of the cutaneous exhaling vessels, and thereby preventing efusion, and subsequent suppuration. It will be apparent that the poulticing is merely a moditication of the same principle as immersion, for the sake of comvenience, and may therefore, under particular exigencies or circumstances, be conmenced at any time.

To Messrs. Nicholson and Tilloch.

IV. On the Agency- of Electricity in constituting the peculiar Properties of Bodies, and producing Combustion. Dy Mr. JoHX Wrisster.

$r$

I HT secondary calses which operate throughout nature are forned with such infinite wisdom and design, by the first great inscruable cause, that it cannot excite our surprise that tinite creatures are unable to fathom or explain these laws, or that there should be various hypotheses concerning them.

Although the advancement that has been nuade in the chenical department of nature is still limited, yct encugh has been done to show the simplicity of her laws and the generality of their operations. When we see principles witlely diftused, we conclude that they are intended for great and impurtant purposes in the œconomy of nature, and that gereral eftects are derived fron these prevailing causes.

Light, heat, and electricity are imponderable elements of universal distribution, and appear to se primiry instruments in the hands of nature. In discovering her laws, we are more induced to speculate on tangible and senible mxsses, thin on these universal principles.

VoL. 43. No. 189. Jan. 1914. 
We consider the eaith as composed of a certain number of elements, and that the different properties of bodies depend upon the different combinations of these elementary substances. Aggregated masses undergo no change in their properties, without sone chemical change amongst the elements that compose them; and as chemical effects are now ascribed to the influence of elcctricity, the change of property which bodies obtain seems to be more peculiarly derived from a variation in the electrical state of them than from any other source.

The most acrid and offending bodies lose their destructive properties by chemical or electrical combination. If it be the property of acids and alkalis to be corrosive, why do they lose their respective properties by combination, if it be not derived from the electrical union of the ultimate particles that compose them ? Even the same elements in the same quantities will receive different properties under different states of electricity. The gas called 1itrous oxide, for instance, is, according to Sir H. Davy, composed of thirty-six parts in a hundred oxygen, the remainder nitrogen; and the atmospheric air twenty-one parts oxygen, and the rest nitrogen, saving some inconsiderable portion of carbonic acid gas. Now suppose fifteen parts oxygen be added to the atmospheric air to bring the quantities of these ponderable elements equal; in this case, we are well aware that the properties of the two gases in the lungs are of a very different description, although their elements are the same, and yct the atmospherical air may be converted into the nitrous oxide by electricity.

According to Cavendish's experiment, if we pass electrical shocks through a confined portion of atmospherical air, we produce nitrous gas ; but in this experiment a portion of the nitrogen is rejected, and the electrical combination of the oxygen with the remaining nitrogen is in greater proportion than in the atmospherical air : if we present even an oxidable metal to the nitrous gas, it loses a portion of its oxygen, and is converted into nitrons oxide.

The different properties of the two elements, oxygen and nitrogen, in these three different states of combination, seem peculiarly to point out how much the properties of bodies are produced by their different states of electricity.

The same principle is strikingly showl from the effects produced by the vinous and acetous fermentations. Oxygen, hydrogen and carbon compose sacharine matter: this in solution undergoes an electrical process called the vinous fermentation, and alcohol is produced from the same elements as the sugar and water. Another electrical change called the acetous fermentation absorbs a further quantity of oxygen, and wine is con- 
verted into vinegar. Thus the properties of the fluid change, as the chemical or electrical combination varies amongst the elementary principles that compose it.

If it be admitted that the character and properties of bodies be derived from electrical influence upon the particles that compose them; the substances themselves are passive, or are merely the vehicles of limited quantities of electricity for which they have a determinate capacity.

Supposing, according to the generally received opinion, that all bodies possess electricity, but in different quantities according to their capacity, comlustion and other chemical effects might be explained upon a new theory.

The term combustion is here employed to express the evolution of light and heat, rather than the decomposition of a body.

According to Lavoisier, combustion arises out of the combination of an inflammabie body with oxygen : hence oxygen has been considered as an essential to corabistion.

Inflammable bodies, generally, have great capacity for electricity, and oxygen of all other bodies the least. Whether we suppose the inflammable body and oxygen to be taken away, or the ultimate particles of these bodies combined ; still the electricities remain the same, and these very opposite states will rapilly combine to restore an electrical equilibrium. In either case, an emission of light and heat will be produced; that is, either with or without the grosser bodies. So that we have all the effects of combustion in an electrical spark obtained from the conductor of an electrical machine, or from the positive and negative endis of the wires of the electro-chemical apparatus, às well as from the combustion which is produced by the electrical combination of the ultimate particles of bodies in opposite states of electricity.

Oxygen, which is considered as indispensable to combustion, may be withdrawn when electricity is supplied.

In the ordinary experiment of burning chareval between the positive and negative ends of the electro-chemical apparatus, the degree of light and heat which is evolved is in preportion to the intensity of electrical power empioyed, and the effect which is produced is grreatly superior to any other means of combustion: this seems to arise from the infueince of uncombined clectrieity.

When combusticn takes place from the corrbination of the particles of two bodies, the effect is limited; or the enission of light and heat is depondent upon the electrical capacitins of the bodies employed: thus, the different combustible dispositions which different bodies possess arise from their varying capacity for electricity, the intensity being the greatest in those bodies that are in the most opposite states. Lut the infuence of un- 
combined electricity in supporting combustion, or producing an evolution of light and heat, is always the most powerful, from the extreme states of the fiuid; and eciually perfect in effect, whether the quantity employed be great or small : it is on this account that the ordinary electric lights are much more brilliant than those that are obtained by any other means.

The influence of cxygen does not appear to produce any effect where uncombined electricity is employed.

If a combustible body, charcoal for instance, be placed in a vessel of nitrogen or hydrogen gas, on connecting it with the two chids o the electro-chemical apparatus, the light is equally brilliant with that which is obtained in atmospherical air: or, if the charcoal be placed under an exhausted receiver, an equal effect will be produced. The combustion of the charcoal is equally vivid in water or carbonic acid gas; but in the two latter instances it might be objected that the bodies were decomposed, and oxygen supplied from them.

Then briefly to sun up this view : the evolution of light and heat, or the gencral effects of what is termed combustion, appears to arise out of the repid union of opposite states of electricity, either independent and uncombined, or effected by means of certain bodies in which it resides; and that the combination of the vilimate particles of sensible masses can only take place through the influence of those portions of electricity for which the bodies have a specific capacity; and that the properties of there bodies arise out of their electrical states : thus generally tendin r. to support those established principles of Sir H. Davy, that all chemical comlination is dependent upon electrical mion.

If these observations should be found worthy of a place in your very useful publication, I shall take another opportunity of extending this subject a little further, and of tracing some of the analogies of light and heat with electricity, and the influence of these universal agents in the oeconomy of nature.

$$
\begin{aligned}
& \text { I am, sir, } \\
& \text { Your obedient servant, }
\end{aligned}
$$

JOHN WEBSTER.

To Messrs. Nictolion and Tilloch.

\section{On Electricity. By GEorge John Singer, Esq.}

Sonz time since, I ventured to rectify some erroneous statements of Mr. Ez. Walker's on the subject of electricity; regarding them as the mistakes of a novice in that science, which it might be useful to correct for the advantage of other young electricians. 